\title{
The Role and Importance of Australia in the South Pacific Region
}

\author{
Miroslaw Przygoda \\ University of Warsaw, Faculty of Management \\ 02-678 Warszawa, ul. Szturmowa 1/3, Poland
}

\begin{abstract}
Australia is a country comprising the mainland of the Australian continent and the island of Tasmania. The country also includes numerous smaller islands in the Pacific and Indian Ocean. Australia is the sixth-largest country in the world by total area. It also has the world's 12th-largest economy and fifth-highest per capita income. On 1 January 1901, a federation of six separate British self-governing states was formed after a decade of planning, consultation and voting. This established the Commonwealth of Australia as a dominion of the British Empire. In 1931 the status of the dominions was made equal to that of Great Britain, which is considered the symbolic date of Australia gaining full independence. Before World War II and in the course of it, the Commonwealth of Australia was closely tied to the government in London. However, the fall of the British Empire in the Asia Pacific made Australian authorities rethink their existence in the new reality. In the late $80 \mathrm{~s}$, Australia's formal ties with London were further loosened, as planned. Since that time the role and significance of the continent has been growing. A vibrant economy and favourable location drive the country's growing importance, which the government in Canberra strongly focuses on. Economic success and effective policies have made Australia become one of the crucial elements of sustainable balance in the South Pacific region. However, the country's political and economic influence goes far beyond its borders. Australia's importance to and influence on neighbouring countries is clearly visible across East and Southeast Asia, the Indian Ocean basin, and the Antarctic. Therefore it is worth to take a closer look at the drivers of the huge success of this unique country and its inhabitants.
\end{abstract}

Keywords: Asia, Australia, Pacific, Region, Success

\section{Introduction}

Looking at a world map from a certain perspective, we immediately notice Asia, i.e. the largest continent in terms of total area. The continent covers 44,580,000 km2, which accounts for $29.8 \%$ of all land on Earth. By comparison, Europe, with its $10,180,000 \mathrm{~km} 2$ accounting for merely $7.1 \%$ of all land on Earth, resembles a large peninsula on the western borders of Asia. Australia, on the other hand, covers only 7,741,220 km2 (not including Oceania). This accounts for nearly 5.2\% of all land on Earth. The smallest continent looks like a huge island, closing the southern gateway to New Zealand and the Antarctic for the entire East and Southeast Asia. However, Australia is, to some extent, linked with the latter region through thousands of smaller and bigger islands and islets, serving as a "bridge". They stretch on the seas which, in geographical terms, belong to the western part of the Pacific Ocean basin. A peripheral country for many centuries, since relatively recently Australia has clearly had more luck. Thanks to fast growing countries such as Japan, South Korea (Wehrfritz, 2002), Taiwan and Singapore, but, most of all, due to the recently robust economic growth of the People's Republic of China, there has been a shift in political and economic powerhouse in favour of East Asia (Cukiernik, 2015). For Australia, a country located "at the end of the world", this has created an excellent opportunity to take part in the new world order, which has been more favourable to Australia's interests than the previous one. Now the smallest of all continents has become a bridge between Asia and the Americas, including on its way New Zealand and other smaller islands of Oceania. With that new perspective, we can see that Australia has started to play a new and significant role in the entire South Pacific region. 


\section{Early Settlement}

Before Europeans came to Australia, it had already been inhabited by the Aborigines. Even today the origins of Australia's oldest inhabitants have not been fully explained. The official version says that the people came from Southeast Asia. The settlement process was supposedly enabled by a land connection, which had existed for some time between Asia and Australia. The Aboriginal people came to the continent in three independent waves around 40-60 thousand years ago. This resulted in quite a diverse population in anthropological terms. Before white settlers arrived, the indigenous people had inhabited various parts of the continent. They pursued a nomadic way of life, on a very low civilization level, by hunting and gathering, and on the coast also by fishing. The first Europeans who arrived in Australia were likely Portuguese in the 16th century. During that time they were setting up their trading posts in India, China and Southeast Asia. Since they perceived Australia as uninhabited and with unfavourable natural and weather conditions, they decided not to settle it. After the Portuguese, Asia Pacific started to be explored by the Dutch. The first Dutchman to reach the coast of Australia in 1606 was Willem Janszoon (1579-1630) on the Duyfken ship. This is where the continent's first name, i.e. New Holland, came from.

The very same year Australia was also discovered by a Spanish sailor Luis Vaez de Torres (1560 - 1613). A bit later, in the years 1642-1644, a Dutchman Abel Tasman (1603 - 1659) sailed along the coast of Australia and discovered an island subsequently named after him. He was the first European who reached Tasmania and New Zealand during a trip organised by the Dutch East India Company in the years 1642 - 1643. In 1770 the south coast of Australia was reached by James Cook, the famous British explorer. He made detailed maps and described the flora of the region. As an explorer, he gave the area the name New South Wales while proclaiming it a dominion of the British Empire. The Brits began colonising the continent from the south coast (New South Wales) only after losing some of their dominions in North America. In 1788 a fleet with the first group of British convicts arrived in the area of today's Sydney. For nearly 80 years thereafter prisoners and criminals would be sent there. The last transport of them came by sea in 1868 to Western Australia. Gradually, though, also voluntary settlers began to flow into the area, driven by the possibility to obtain arable land. Also, more and more people came to breed sheep and cattle, which was seen as a way to get rich fast. Taking up new land for pastures in the interior accelerated the settling of the continent and an influx of colonists also from other European countries. Increased food production allowed for becoming independent from food supplies from the metropolis. The newcomers took over the Aborigines' land and exterminated them ruthlessly. As the settlement advanced, new colonies emerged: Western Australia in 1829, South Australia in 1834 and, isolated from New South Wales: Tasmania in 1825, Victoria in 1851, and Queensland in 1859. Their autonomy was also gradually extended. The wave of immigrants increased dramatically as a result of "gold rush", when in 1851 gold deposits were discovered first in Victoria and New South Wales and then in Queensland and Western Australia.

All sorts of explorers and wranglers came in masses, and the settlements they established gradually turned into cities which continue to exist today. Fast growth of agricultural production allowed for becoming independent from food supplies the metropolis. However, the development of agriculture and demand for new land gradually eliminated the Aborigines and pushed them into areas least fit for living. The discovery of iron ore and non-ferrous metals in the late 20th century triggered the dynamic growth of the industry, mainly mining and processing. This resulted in the emergence of rail transport, public roads, and telegraphy. The development of industrial infrastructure generated the demand for workforce. This caused the influx of immigrants from Great Britain, other European countries, the USA, and Asia. Each of the existing colonies functioned as a separate entity with different laws and regulations. Such situation made everyday life and cooperation very hard. For example, in every colony the railway tracks had different spacing. In many cases, also different legal regulations existed. This really hampered the country's economic growth. In the 90s of the 19th century, the strive for establishing a federation of colonies increased. In large part, this was due to the emergence of the feeling of national identity among the continent's inhabitants. On 1 January 1901, after Great Britain had adopted the Australian Commonwealth Act, a dominion of the Commonwealth of Australia was established, with its own constitution, government, and parliament. The former colonies have gained the status of states. Also, a decision was taken to establish the capital of the Federation. With joint efforts, Canberra was built.

\section{Australia in the $20^{\text {th }}$ Century}

In the very beginning of the 20th century, Australia constituted a single, unified country, forming part of the British Empire. For the whole time until the outbreak of World War I, it maintained close ties with the metropolis. By taking advantage of the legal regulations in place, which favoured British products in foreign trade, Australia profited from 
existing privileges. This ensured continuous demand for products of sheep and cattle breeding and for the sale of excess agricultural produce at preferential rates. This policy contributed to the country's further dynamic growth, visibly improving the standards of living for the white population. Under the legal system taken over from the British, progressive political and social ideas were quickly adopted. Very soon women were granted voting rights. Nationwide it took place in 1902, but in South Australia eight years earlier. A modern tax system was introduced, along with pensions, social insurance, and other social benefits. Australia became a poster child of a welfare state, a situation which to a large extent has continued until today. During the Second Boer War (1899-1902), Australia took the British side. During the conflict, it sent its troops to support London's intervention in South Africa. During World War I, Australian soldiers fought on many fronts hand in hand with other nations of the Empire.

A great deal of Australians lost their lives during the Turkish campaign on Gallipoli Peninsula, heavily defended by the Ottoman army. In total, more than 28,000 Australian soldiers died or were injured during the campaign (Chwalba A., 2014). Anzac Day, 25 April, is today one of Australia's most important national remembrance days. It marks the anniversary of the first major military action fought by Australian and New Zealand forces during the First World War on Gallipoli Peninsula. ANZAC stands for Australian and New Zealand Army Corps. The soldiers in those forces became known as Anzacs, and the pride they took in that name endures to this day.

As a political consequence of World War I, the autonomy of British dominions was extended. Australia attended the Paris Peace Conference in 1919, which ended the global armed conflict, as independent subject of international law. This was enabled by Australia's joining, as one of the founding states, the League of Nations in 1920. At the Imperial Conference in 1926, transforming the British Empire into a Commonwealth of Nations was proclaimed. This was confirmed by the British parliament in 1931 in the so called Statute of Westminster. Under the document, the dominions were made equal in their status with Great Britain. The international community acknowledged the independence of the individual states belonging to the Commonwealth. What still binds them together is the recognition of the British monarch as the head of state. Today Australia continues to be bound in a personal union with Great Britain, which means that every new king or queen on the British throne is simultaneously the head of Australia. The monarch is the formal head of state and commander-in-chief, and also heads the executive branch (Bozyk S., 2001).

Since most of the time the British monarch resides outside Australia, all the tasks at the federal level are performed by the governor general. The period of economic growth which began after World War I triggered the dynamic development of the country and made its white citizens increasingly wealthy. However, repercussions of the Great Depression of the 30s did not spare the continent. Price drops on international markets and a lack of demand for meat, wool, crops and industrial products badly hit Australia's economy. There was a collapse, mainly in exports. High unemployment followed and poverty emerged. In many areas the effects of the Great Depression were visible even towards the end of the decade. The then existing conditions in the world did not help in fighting them either. The growing military threat from the Empire of Japan and the diminishing influence of London in the region only made the situation worse. After the outbreak of World War II, Australians traditionally sided with Great Britain to fight common enemies. They defended the ideals of the Commonwealth of Nations and showed their bravery at the front as well as attachment to the king. However, in the conflict, Canberra's land forces did not play such a significant role as in World War I. It was mainly the Royal Australian Navy (RAN) and Royal Australian Air Force (RAAF) which marked their participation in the conflict. As early as in 1940 the joint staff of Japan's Army and Navy reached a consensus on the direction of the expansion. This was to include Southeast Asia, with countries such as French Indochina, the Philippines, Dutch East Indies, as well as Thailand and Myanmar, situated in the same area. Seizing these areas would enable the Empire of Japan to gain access to very abundant natural resources needed to run the war.

In this context, Australia became the strategic goal of the conquest. For the allies, the country was a key place in the South Pacific region. If it had been captured, Japan's domination over the entire area would have lasted much longer than two years. The conflict would have claimed a lot more lives, introduced fundamental changes in the theatre of war, and surely prolonged the war for a few years. The fall of the Malays and Singapore in 1942 made Australians realise the scale of danger from Tokyo (Jackson R., 2008). The British, Australian, Indian and Malayan troops failed to withstand the attack of the Imperial Japanese Army. No help from London was also noticeable. This made John Curtin (1885-1945), the Prime Minister leading two consecutive cabinets, revise his policy and enter into close cooperation with the USA (Crowley F. K., 1973). As a result, Australia became one of the most important permanent American bases in southwest part of the Pacific Ocean and America's close ally in the region. The war directly affected Australia's territory. In the years 1942-1943 Japan's air forces launched more than 100 airstrikes in the north of the country. The two largest ones, 
i.e. on Darwin, the capital of Northern Territory, were conducted on 19 February 1942. The port and the city were more heavily bombed than the O'ahu island in the Hawaii on 7 December 1941. For this reason, in historiography, the Darwin attack started to be referred to as the "Australian Pearl Harbor", despite a lot fewer losses suffered by Americans (Kaczmarek R. M., 2004). During World War II, the Japanese correctly assessed Australia's location and resources, which were key for their strategy and success of the entire Asian campaign. Therefore, almost until the end of military actions in the region, the Japanese undertook efforts to prepare conditions for their invasion. This can be found in accounts of contacts between Imperial Army's scouts and the Aborigines in the northern part of the continent and the existence of secret Japanese bush airfields in Australia during WW2. However, these accounts have never been confirmed. Also, the issue of special Occupation Money, i.e. a version of currency to be used in Australia, was being prepared.

After the war, Australia enjoyed an economic boom. This resulted from the huge global demand for food, wool, and industrial goods, brought about in part by further strengthening of political, economic and military cooperation between Australia and United States. In 1951, the ANZUS security treaty was signed. The Australia, New Zealand, United States Security Treaty (ANZUS or ANZUS Treaty) is the 1951 collective security agreement which binds Australia and New Zealand and, separately, Australia and the United States, to co-operate on military matters in the Pacific Ocean region, although today the treaty is taken to relate to conflicts worldwide. It provides that an armed attack on any of the three parties would be dangerous to the others, and that each should act to meet the common threat (ANZUS, 2016). As part of the United Nations deployment, Australia had earlier fought alongside the United States in the Korean War (19511953). A decade later, based on the ANZUS treaty, Australian troops took part in the Vietnam War in the years 19641973.

In 1987 the United States announced that the treaty ceased to apply in relations with Wellington. The reason was that the government of New Zealand declared that its country had become a nuclear-weapons-free-zone. However, Australia, which has strong historical, cultural and emotional ties with New Zealand, continues to regard the country as a fullfledged member of the treaty. Despite considerable pressure from the US, the Australian government relentlessly continues its own policy in this respect.

As far as the economy is concerned, in 1989, at Australia's initiative, it was decided to establish APEC (Asia-Pacific Economic Co-operation). Initially, its members included: Australia, Brunei, Canada, Indonesia, Japan, South Korea, Malaysia, New Zealand, the Philippines, Singapore, Thailand, and the United States. In later years they were joined by China, Hong Kong, Taiwan, Mexico, Papua New Guinea, Chile, Peru, Russia, and Vietnam, followed by India, Bangladesh, Guam, Fiji, Pakistan, Sri Lanka, Macau, Mongolia, Laos, Cambodia, Costa Rica, Colombia, Panama, and Ecuador, which were among a dozen other economies that have applied for membership in this organisation. The Asia-Pacific Economic Cooperation is a regional economic forum established to leverage the growing interdependence of the Asia-Pacific and Australasia. APEC's 21 members aim to create greater prosperity for the people of the region. Their intension is to achieve spectacular results by promoting balanced, inclusive, sustainable, innovative and secure growth and by accelerating regional economic integration. APEC ensures that goods, services, investment and people move easily across borders. Members facilitate this trade through faster customs procedures at borders, more favourable business climates and aligning regulations and standards across the region (APEC, 2016). Today APEC forms the world's most robust and fastest growing economic area.

\section{Modern Australia}

In the second decade of the 21st century Australia is a modern and developed country, whose economic potential by nominal GDP makes it the 12th largest economy in the world. Australia has the fifth-highest per capita income in the world. The Australian economy is dominated by its service sector, comprising $68 \%$ of GDP. The mining sector represents $7 \%$ (Value, 2012) of GDP; including services to mining, the total value of the mining industry in 2009-10 was $8.4 \%$ of GDP (Mining Industry, 2012). Economic growth is largely dependent on the mining sector and agricultural sector (12\% of GDP) with the products to be exported mainly to the East Asian market (Farm Facts, 2012). Table 1 features Australia's economic situation in the years 2011-2015.

Table 1: Australia Economy Data (2011 - 2015)

\begin{tabular}{|l|l|l|l|l|l|l|}
\hline No. & Subject & 2011 & 2012 & 2013 & 2014 & 2015 \\
\hline
\end{tabular}


Miroslaw Przygoda

The Role and Importance of Australia in the South Pacific Region

\begin{tabular}{|c|l|l|l|l|l|l|}
\hline 1. & Population (million) & 22.5 & 22.9 & 23.3 & 23.6 & 23.9 \\
\hline 2. & GDP per capita (USD) & 66,807 & 68,020 & 64,615 & 61,203 & 51,320 \\
\hline 3. & GDP (USD bn) & 1,504 & 1,559 & 1,506 & 1,444 & 1,225 \\
\hline 4. & $\begin{array}{l}\text { Economic Growth } \\
\text { (GDP, annual variation in \%) }\end{array}$ & 2.7 & 3.6 & 2.0 & 2.7 & 2.4 \\
\hline 5. & $\begin{array}{l}\text { Consumption } \\
\text { (annual variation in \%) }\end{array}$ & 3.2 & 2.3 & 1.7 & 2.8 & 2.8 \\
\hline 6. & Investment (annual variation in \%) & 7.0 & 9.2 & -1.8 & -1.9 & -3.9 \\
\hline 7. & $\begin{array}{l}\text { Exports (Goods and Services, } \\
\text { annual variation in \%) }\end{array}$ & 0.1 & 5.8 & 5.9 & 6.7 & 6.0 \\
\hline 8. & $\begin{array}{l}\text { Imports } \\
\text { (G\&S, annual variation in \%) }\end{array}$ & 11.1 & 6.1 & -1.8 & -1.7 & 1.7 \\
\hline 9. & $\begin{array}{l}\text { Industrial Production } \\
\text { (annual variation in \%) }\end{array}$ & 1.2 & 3.3 & 2.1 & 4.5 & 1.6 \\
\hline 10. & Unemployment Rate & 5.1 & 5.2 & 5.7 & 6.1 & 6.1 \\
\hline 11. & Public Debt (\% of GDP) & 24.2 & 27.8 & 30.8 & 34.1 & 36.8 \\
\hline 12. & Exchange Rate (vs. USD) & 1.02 & 1.04 & 0.89 & 0.82 & 0.73 \\
\hline 13. & $\begin{array}{l}\text { Infation Rate (CPI-consumer price index, } \\
\text { annual variation in \%) }\end{array}$ & 3.3 & 1.8 & 2.5 & 2.5 & 1.5 \\
\hline 14. & $\begin{array}{l}\text { Stock Market } \\
\text { (annual variation in \%) }\end{array}$ & -15.2 & 13.5 & 14.8 & 0.7 & -0.8 \\
\hline 15. & Trade Balance (USD billion) & 35.9 & 6.2 & 20.5 & 12.2 & -11.9 \\
\hline
\end{tabular}

Source: Focus economics website

The Australian economy has been plunging since 2013 and did not overcome the downward trend in 2014 or 2015. Conservative forecasts suggest poor economic figures for 2016, too. The international situation, in particular the slowdown in the People's Republic of China, i.e. Australia's largest trade partner, is mostly to blame for the biggest recession in 50 years (Australian economy, 2015). Expanding credit and dependence on China make Australia vulnerable to global shocks. Poor economic performance of Canberra's other important partners, namely the USA, Japan, and the European Union, have also had a negative impact on the results. The drop in prices of products traditionally exported by Australia, such as coal, iron ore, aluminium, bauxites, meat, wool, wheat and barley, has further worsened the already bad situation. It seems that the country in the Antipodes is experiencing the biggest economic downturn in its contemporary history. A few years ago nothing indicated this, as luckily none of the three waves of the global financial crisis of 2008 reached Australia. One can only hope that the current government, led by Malcolm Turnbull, an experienced politician aware of the country's difficult situation, will be able to address these problems.

\section{Australia's Political and Economic Importance in the Region}

Australia is a developed country. The country's economy is characterised by technologically advanced, highlyconcentrated production and centralisation of capital. The world's smallest continent has enormous natural resources. Australia is a leader in mining bauxites, iron ore, lead, and gold. It also has silver, uranium, zinc, copper, and nickel. Mining and processing of oil and natural gas are conducted on a large industrial scale. There are also abundant deposits of precious stones, including sapphire and opals. After discovering abundant diamond deposits in 1979, Australia caught up with South Africa in their production. There is a diversified industrial sector, in which $25 \%$ of the working population works. The sector accounts for around $27 \%$ of gross domestic product. Mostly food and tobacco products are produced, but the machine and high-tech industries are also highly developed. Recently Australia's showcases in this respect include computers, chemicals, and car manufacturing. There are even local car manufacturers, for example Holden (part of General Motors) or Ford Australia. However, in this field it is not easy to match strong foreign competition. Japanese carmakers, such as Mitsubishi, Nissan and Toyota, also have their factories on the continent. Production of huge trucks, which form the so called "road trains" passing through the Australian interior, has been dominated by America's Mack Trucks, Inc. from North Carolina (Mack Trucks, 2016).

Agriculture is one of the main sectors of Australia's economy. Farming land covers in total ca. 385 mln ha $(3,850,000$ $\mathrm{km})$. This accounts for nearly half of the country's total area. Agricultural production is concentrated primarily in the eastern part of the country, mostly in Queensland, New South Wales, and Victoria. Arable land accounts for only around 
$5 \%$ of the total area, whereas meadows and pastures constitute ca. 57\% of the country's farming land (Moldawa T., 1992). The country is the world's top producer and exporter of wool. It also exports meat, primarily lamb and beef, dairy products, and crops. Even sugarcane, bananas and pineapples are grown in the subequatorial and tropical climate. In the subtropical climate, wheat (53\% of all crops), barley, oat, cotton, citruses, and grapes of which excellent Australian wines are made, are grown. However, Australia's economy in large part depends on the world's economic situation and prices on the global market. Around $70 \%$ of its export accounts for natural resources and agricultural produce.

The Australian dollar is the currency of the Commonwealth of Australia and its territories, including Christmas Island, Cocos (Keeling) Islands, and Norfolk Island. It is also the official currency of the independent Pacific Island nations of Kiribati, Nauru and Tuvalu. Australia is a member of the APEC, G20, OECD, Pacific Islands Forum and WTO. The country has also entered into free trade agreements with ASEAN, Canada, Chile, China, Korea, Malaysia, New Zealand, Japan, Singapore, Thailand and the United States (Free Trade, 2016). The ANZCERTA agreement with New Zealand has greatly increased integration with the economy of New Zealand and in 2011 there was a plan to form an Australasian Single Economic Market (ANZCERTA, 2016).

Also very important is the Australia - United States Free Trade Agreement (AUSFTA). It is a preferential trade agreement between Australia and the United States modelled on the North American Free Trade Agreement (NAFTA). The AUSFTA was signed on 18 May 2004 and came into effect on 1 January 2005. Special tariff rate quotas are part of the agriculture section of the agreement. These quotas allow Australian producers to export increasing amounts of these products free of duty to the United States during the tariff elimination period. The following agricultural products are designated: beef, dairy, tobacco, cotton, peanuts, avocados (Armstrong S., 2015). Nonetheless, the regional economic cooperation with Beijing is most important for Australia's economy. The relations between Australia and China are characterised by strong trade bonds. China is Australia's largest trading partner, while Australia is a leading source of resources for China. More recent trends show that Australian exports are now expanding well beyond the resource sector. In recent years, new life has been breathed into negotiations for a free trade agreement between the two countries. During the then Prime Minister Tony Abbott's April 2014 visit to Beijing, there were encouraging signs that an agreement could be reached before the end of 2014, and in the wake of the Brisbane G20 Summit in November 2014 the deal's draft details were released. The deal (known as ChAFTA) was formally signed in June 2015, and in October 2015 Opposition Leader Bill Shorten announced that Labour would back the deal after reaching a compromise with the Government on elements of the agreement, giving the deal bipartisan support (Relations, 2016). The two-way trade between Australia and the world is presented in Table 2 .

Table 2: Australia's top two-way trading partners in 2014(goods \& services trade in $\$$ billion)

\begin{tabular}{|c|l|c|c|c|}
\hline Rank & \multicolumn{1}{|c|}{ Country } & Exports & Imports & Total trade \\
\hline 1. & China & 98.210 & 54.258 & 152.468 \\
\hline 2. & Japan & 50.247 & 19.971 & 70.218 \\
\hline 3. & United States & 18.510 & 41.932 & 60.442 \\
\hline 4. & Republic of Korea & 22.017 & 12.609 & 34.626 \\
\hline 5. & Singapore & 12.085 & 18.102 & 30.187 \\
\hline 6. & New Zealand & 12.125 & 11.343 & 23.468 \\
\hline 7. & Malaysia & 7.923 & 12.873 & 20.796 \\
\hline 8. & United Kingdom & 8.319 & 12.469 & 20.788 \\
\hline 9. & Thailand & 6.105 & 12.873 & 18.978 \\
\hline 10. & Germany & 2.867 & 13.859 & 16.725 \\
\hline
\end{tabular}

Source: dfat.gov.au website

When analysing Table 2, one can notice that Australia has a trade surplus with China, Japan, Republic of Korea, and New Zealand, whereas it imported more goods and services from other countries from the top ten list, namely the United States, Singapore, Malaysia, United Kingdom, Thailand, and Germany. Also, it can be clearly seen that the majority of Australia's trade is with East and Southeast Asia. One exception here is the United States. For United Kingdom and New Zealand, the relatively high level of two-way trade is due to historical conditions. 
In 2015 there was a fundamental change in the second and third place among the top two-way trading partners. China was still Australia's largest individual two-way goods and services trading partner, accounting for 23.2\% (USD 155.5 billion) of total trade. But the United States was the second largest trading partner accounting for $10.5 \%$ (USD 70.2 billion) followed by Japan, accounting for 9.7\% (USD 65.1 billion). China was Australia's largest export market, accounting for $28.8 \%$ (USD 91.3 billion) of total exports in 2015, a drop of 7.0\%. Japan was Australia's second largest export market (USD 42.4 billion), a drop of 15.7\%. The United States of America was Australia's third largest export market (USD 22.1 billion), up by 19.3\%. China was Australia's largest import source, accounting for 18.2\% (USD 64.2 billion) of total imports in 2015, up by $18.3 \%$. The United States was Australia's second largest import source (USD 48.1 billion), up by $14.3 \%$, and Japan was Australia's third largest import source (USD 22.7 billion), up by $14.4 \%$ (Composition of trade, 2016). The considerable economic slowdown in China, Japan and the United States badly hit Australia's trade figures in 2015. According to initial estimates, 2016 did not bring any significant improvement either. Nonetheless, Australia is one of the most important trade player in East Asia and, in a broader sense, in the entire Pacific Ocean basin. The country's political activity and membership in many international organisations of local and global importance improve stability of the whole region.

\section{Conclusion}

Australia's economy relies heavily on exports. Considering Australia's small internal market, the potential limitation of the ability to sell goods and services to foreign countries would threaten the country's economic existence. Among the top trading partners there are basically only three that matter, i.e. China, the United States, and Japan. The other ones would not be able to absorb the continent's exports. However, all the three economic powers, i.e. China, the USA, and Japan, are not dependent on trade with Australia and do not have to rely on resources from that country. China is strengthening its resources cooperation with Russia. Recently Tokyo has been taking steps to break the deadlock in contacts with Moscow (Putin in Japan, 2016). The United States have their own resources and, as part of NAFTA, also access to the resources of its northern neighbour Canada. Therefore, the direction of Canberra's foreign trade policy seems adequate in today's situation. Seeking a fine balance with the three main partners while diversifying trade contacts with smaller market players to the largest extent possible is a reasonable and currently probably the only solution. However, a question should be asked:

Could Australia become an economic power and single-handedly drive the economic situation in the region?

Unfortunately, the answer to this question is no. Currently Australia does not have the right amount of human capital to achieve such position. The continent's population was and continues to be a few times too small to handle the challenge of dominating the South Pacific and East Asia. It is obvious that in today's world it is mainly the countries with a population of more than 100 million that matter. Table 3 shows a few examples confirming the trend.

Table 3: List of countries by population

\begin{tabular}{|c|l|c|c|c|}
\hline Rank & Country & Population & Date & $\begin{array}{c}\text { \% of world } \\
\text { population }\end{array}$ \\
\hline 1. & China & $1,380,530,000$ & 21 December 2016 & $18.5 \%$ \\
\hline 2. & India & $1,309,510,000$ & 21 December 2016 & $17.5 \%$ \\
\hline 3. & United States & $325,192,000$ & 21 December 2016 & $4.35 \%$ \\
\hline 4. & Indonesia & $260,581,000$ & 1 July 2016 & $3.49 \%$ \\
\hline 5. & Brazil & $206,856,000$ & 21 December 2016 & $2.77 \%$ \\
\hline 9. & Russia & $146,727,405$ & 1 September 2016 & $1.96 \%$ \\
\hline 10. & Japan & $126,920,000$ & 21 December 2016 & $1.7 \%$ \\
\hline 11. & Mexico & $122,273,000$ & 1 July 2016 & $1.69 \%$ \\
\hline 12. & Philippines & $101,953,000$ & 21 December 2016 & $1.39 \%$ \\
\hline $\mathbf{5 3 .}$ & Australia & $\mathbf{2 4 , 4 6 8 , 0 5 7}$ & $\mathbf{2 3}$ December 2016 & $\mathbf{0 . 3 3 \%}$ \\
\hline
\end{tabular}

With its population of slightly more than 24 million, Australia is far down the list, in the 53rd place. Although Australia's population is continuously growing, in recent years this has been due to hundreds of thousands of immigrants rather than the birth rate of its own citizens. Today's immigrants are essentially people coming from all over the world. This complicates and diversifies ethnic relations in the continent. However, already in the 60s of the last century, the 
government in Canberra abandoned the idea of a "white Australia". Today, in addition to immigrants from Englishspeaking countries, such as Great Britain, New Zealand, the United States, South Africa, Ireland, and Canada, more and more people come from East Asia and Central Asia, from countries such as China, India, the Philippines, Vietnam, Malaysia, Sri Lanka, South Korea, Hong Kong, Indonesia, Iraq, Thailand, Nepal, Bangladesh, Afghanistan, Uzbekistan, Taiwan, or Pakistan. In 2014-15, net overseas migration reflected an annual gain of 168,200 persons, down by $9.8 \%$ from 2013-14. An estimated 339,000 people moved interstate in 2014-15, down by $2.9 \%$ from the previous year. As at 30 June 2015, 28.2\% of Australia's estimated resident population (6.7 million people) was born overseas (Migration, 2016). The current population of Australia is 24,468,057 as of Wednesday, 21 December 2016, based on the latest United Nations' estimates. Australia's population accounts for $0.33 \%$ of the total world population. Australia ranks number 53 in the list of countries (and dependencies) by population. The population density in Australia is 3 per km2 ( 8 people per mi2). 89.3 $\%$ of the population is urban $(21,692,663$ people in 2016). The median age in Australia is 37.6 years (Population of Australia, 2016).

To sum up, it should be said that in addition to positive factors, such as a shift of the world's political and economic powerhouse to East Asia and inclusion of Australia, or successful trade cooperation between Canberra and Beijing, there are conditions which are not conducive to the dynamic growth of the world's smallest continent. These conditions include the uncertainty around the future policy of the United States under the new president Donald Trump and the People's Republic of China's dangerous territorial expansion southwards. Therefore, possible scenarios include the further strengthening of political, economic and military cooperation with New Zealand, i.e. Australia's traditional ally in the region. The post-Brexit Great Britain also gives some hope of developing cooperation and renewing old ties. However, it seems that the most important factor will be the return of strong economic growth in the Asia Pacific. It should be assumed that with joint efforts, the growth will return within the next few years, a situation which is desired and anticipated by all countries of East Asia and the South Pacific basin.

\section{References}

- Armstrong S., (2015), The costs of Australia's free trade agreement with America. Inside Story, National Affairs.

- Bozyk S., (2001). System konstytucyjny Australii. Wydawnictwo Sejmowe, Warsaw.

- Cukiernik T., (2015). Opracowanie pod tytulem: Azjatyckie tygrysy.

- Chwalba A., (2014). Samobojstwo Europy, Wielka Wojna 1914 - 1918, Wydawnictwo Literackie.

- Crowley F. K., (1973). Modern Australia in Documents: 1939 - 1970, A Documentary History of Australia, series; 1, Published by: Wren Publishing. Melbourne.

- Jackson R., (2008). The Malayan emergency, Published by: Pen \& Sword Aviation. London.

- Kaczmarek F.M., (2004), Australijski Pearl Harbor, Morza, Statki i Okręty, No. 3/2004, Published by: Magnum X. Warsaw.

- Moldawa T, (1992), Australia, Związek Australijski. Państwa Świata, Słownik szkolny, Wydawnictwo szkolne i Pedagogiczne. Warsaw.

- Wehrfritz G., Koreanska lekcja ekonomii, Biznes, Newsweek Polska, 13.10.2002, No. 42, p. 42, 2002, Warsaw.

- ANZCERTA, (2016). Australia New Zealand Closer Economic Agreement, Australia unlimited.

- APEC, Asia - Pacific Economic Cooperation (2016).

- Australian economy. (2015). Australia's economy has slowed to a crawl, prompting fears we may be slipping into a recession.

- Composition of trade. (2016). Composition of trade, Australia 2015, Economic Diplomacy, Trade Advocacy \& Statistics Section Department of Foreign Affairs \& Trade, Australia unlimited.

- Economy Data. (2016). Australia Economy Data, Focus Economics.

- Farm Facts. (2012). National Farmer's Federation.

- Free Trade. (2016). Free Trade Agreements, Australia unlimited.

- Mack Trucks. (2016). Mack Missin/Origin/Trademark, Mack Trucks Webside.

- Migration, (2016). 3412.0 - Migration, Australia, 2014 - 15, Australian Bureau of Statistic.

- Mining Industry - Economic Contribution. (2012). 1301.0 - Year Book Australia 2012, Australian Bureau of Statistic.

- Population of Australia. (2016). Australia Population, worldometers.

- Putin in Japan. (2016). Putin w Japonii, Czy przelamie wieloletnia atmosfere nieufnosci? 
- Relations. (2016). China - Australia relations, Lowy Institute for International Policy, Asia / Australia in the World,

- $\quad$ Trading partners. (2015). Australia's top two-way trading partners in 2014.

- Australia's trade at glance, Australian Govn., Department of Foreign Affairs and Trade,

- Value of goods and services produced by Australian industry. (2012). 1301.0 - Year Book Australia 2012, Australian Bureau of Statistic. 